\title{
Prevalence of thyroid dysfunction in women with abnormal uterine bleeding in reproductive age
}

\author{
Hema K. R. ${ }^{1}$, Girish B. L. ${ }^{1 *}$, Dhananjaya B. S. ${ }^{1}$, Riyaj Ahmad Kalaburgi ${ }^{2}$
}

\begin{abstract}
${ }^{1}$ Department of Obstetrics and Gynecology, Sri Siddhartha Medical College, Tumakuru, Karnataka, India
${ }^{2}$ Department of Community Medicine, Sri Siddhartha Medical College, Tumakuru, Karnataka, India
\end{abstract}

\author{
Received: 11 April 2020 \\ Revised: 22 May 2020 \\ Accepted: 28 May 2020 \\ *Correspondence: \\ Dr. Girish B. L. \\ E-mail: drgirish_bylak@yahoo.com
}

Copyright: ( $)$ the author(s), publisher and licensee Medip Academy. This is an open-access article distributed under the terms of the Creative Commons Attribution Non-Commercial License, which permits unrestricted non-commercial use, distribution, and reproduction in any medium, provided the original work is properly cited.

\begin{abstract}
Background: Abnormal uterine bleeding (AUB) is one of the commonest presentations encountered in gynecological outpatient department. Menstruation is also regulated by many mechanisms, including thyroid hormone. So, for definitive management of AUB, it becomes imperative to assess thyroid status in those with abnormal uterine bleeding.

Methods: Cross sectional study was conducted on all woman attending to OPD at Sri Siddhartha Medical College, Tumukuru, with complaints of abnormal uterine bleeding (AUB). Thyroid test was done for those who were eligible under inclusion criteria. Incidence of thyroid disorders among AUB and type of abnormal menstrual pattern associated with specific type of thyroid dysfunction were noted in this study.

Results: Total of 522 presented with AUB. AUB was most common among woman age $>40$ years at $49.23 \%$ (257 of total 522 cases). AUB was more common in Multipara at $61.49 \%$ (321 of 522 cases). Menorrhagia was commonest pattern in AUB accounting for 51.34\% (268 of 522cases). Thyroid dysfunction was present in $12.27 \%$ (64 of 522 ) of cases with AUB. Among them hypothyroid was most common accounting for $8.81 \%$ (46 of 522 cases). Hyperthyroidism was present in $3.44 \%$ (18 of 522 cases). Menorrhagia was most common pattern in Hypothyroidism at $65.21 \%$ (30 of 46 cases, followed by polymenorrhea at $17.39 \%$ ( 8 of 46 cases). Oligomenorrhea was most common in hyperthyroid group at $55.54 \%$ (10 of 18 cases) closely followed by hypomenorrhea at $44.44 \%$ ( 8 of 18 cases).

Conclusions: Abnormal uterine bleeding (AUB) is one of the commonest gynecological complaint at gynecological OPD. Thyroid dysfunction is noted consistently in cases of AUB. So, evaluation of thyroid profile should be part of evaluation of AUB, especially during perimenopause.
\end{abstract}

Keywords: Abnormal uterine bleeding, Hyperthyroidism, Hypothyroidism, Perimenopause, Thyroid disorder

\section{INTRODUCTION}

Abnormal uterine bleeding (AUB) is one of the most common gynecological complaint representing many underlying clinical conditions. It affects nearly affects 9$14 \%$ of woman between menarche to menopause, thereby affecting the quality of life and causing economic burden. ${ }^{1}$ PALM-COEIN is a useful acronym provided by FIGO, 2018 to classify etiology of abnormal uterine bleeding (AUB). $1^{\text {st }}$ portion describes structural disorders and second part describes non-structural disorders. ${ }^{2}$

Thyroid gland is one of largest endocrine gland situated in the neck and weighs about 20 grams in an adult. It secretes two major hormone, thyroxin and triiodothyronine, which are controlled by thyroid stimulating hormone secreted by anterior pituitary. It is known to be one of the most versatile hormone which has 
effect on human body starting from womb to tomb. Some of the important functions includes cell differentiation, body growth, basal metabolism and reproductive physiology. Thyroid gland controls gonads by a combination of direct metabolic effect as well as excitatory and inhibitory control of gonads through gonadotropins and prolactin from anterior pituitary. ${ }^{3}$

Thyroid disorders are more common in women than in men. Also, the female reproductive system is more closely associated with female reproductive system than male as evidenced by goitrous enlargement during menarche, pregnancy and menopause. Delayed puberty, precocious puberty, menstrual disturbances and infertility have been observed in association with thyroid disorders. ${ }^{4}$

Thyroid dysfunction, both hypothyroidism and hyperthyroidism can be associated with abnormal uterine bleeding. The earliest association of thyroid disorder with menstrual disturbance was noted by Basedov in 1840 . He observed association of amenorrhea with hyperthyroidism. Hypothyroidism can cause AUB, including menorrhagia. Hyperthyroidism can result in oligomenorrhea or amenorrhea.,

The association of thyroid disorder with thyroid abnormality has not been studied or published in the geographical region where this study is conducted. So, this study is taken to look for the burden of thyroid dysfunction on AUB.

\section{METHODS}

Cross sectional study was conducted at department of obstetrics and gynecology, outpatient department, SSMC, Tumukuru. The study population was, those women who presented to OPD with complaints of abnormal uterine bleeding (AUB). The study was done from July 2109 to November 2019. The data was entered in excel spread sheet.

\section{Inclusion criteria}

- All woman from puberty to menopause presenting to outpatient with abnormal uterine bleeding (AUB) in reproductive age group.

\section{Exclusion criteria}

- All other causes listed in PALM-COEIN Classification for AUB except thyroid dysfunction

- Those who had other causes along with thyroid dysfunction

- Those with subclinical thyroid dysfunction

- Those with postmenopausal bleeding/premenarchal uterine bleeding.

Complete history was noted down. General physical examination, systemic and pelvic examination were done with the intent of diagnosis for cause of AUB. Relevant investigation like complete blood count, USG, bleeding time, clotting time, FBS, S. prolactin and thyroid profile were done.

Thyroid test included serum TSH, S. T4 and S.T4.

Normal reference range is as follows:

- $\quad$ S. TSH - 0.45-4.5 $\mu \mathrm{U} / \mathrm{ml}$

- $\quad$ S. Free T4 - 0.7-1.9 ng/dl

- S. Free T230 - 619 pg/dl.

\section{Statistical analysis}

All qualitative variables were presented with frequencies and percentages. The association between categorical variables were tested using Chi-square test. The data was analyzed using SPSS software (version 20).

\section{RESULTS}

The total number of cases studied as AUB were 522. The disorder was more common in age group 40 years and older accounting for $49.28 \%$ (257 of total 522 cases).

Table 1: Distribution of cases as per age.

\begin{tabular}{|lll|}
\hline Age group & Frequency & Percentage \\
\hline$<20$ & 90 & $17.24 \%$ \\
\hline $21-30$ & 34 & $6.51 \%$ \\
\hline $31-40$ & 141 & $27.01 \%$ \\
\hline$>40$ & 257 & $49.23 \%$ \\
\hline Total & 522 & $100 \%$ \\
\hline
\end{tabular}

Table 2: Distribution of cases as per parity.

\begin{tabular}{|lll|}
\hline Parity & Frequency & Percentage \\
\hline Nullipara & 96 & $18.39 \%$ \\
\hline Primipara & 105 & $20.11 \%$ \\
\hline Multipara & 321 & $61.49 \%$ \\
\hline Total & 522 & $100 \%$ \\
\hline
\end{tabular}

Table 3: Menstrual disturbance pattern in AUB.

\begin{tabular}{|lll|}
\hline Compliant & Frequency & Percentage \\
\hline Menorrhagia & 268 & $51.34 \%$ \\
\hline Polymenorrhea & 111 & $21.26 \%$ \\
\hline Oligomenorrhea & 73 & $13.98 \%$ \\
\hline Hypomenorrhea & 70 & $13.40 \%$ \\
\hline Total & 522 & $100 \%$ \\
\hline
\end{tabular}

AUB was more common amongst multiparous woman contributing to $61.49 \%$ (321 of total 522 cases).

The most common menstrual disorder pattern seen in AUB was menorrhagia which was $51.34 \%$. (268 of total 
522 cases). Next commonest was polymenorrhea at $21.26 \%$ (111 of 522 cases).

The thyroid status was studied in all AUB cases and the percentage of thyroid abnormality was found in 64 cases (12.27\%), including hypothyroidism and hyperthyroidism. Euthyroid, hypothyroid and hyperthyroid were $87.73 \%$ (458 of 522 cases), $8.81 \%$ (46 Of 522 cases) and $3.44 \%$ (18 of 522 cases) respectively.

Majority of the hypothyroid cases were in age group $>40$ years accounting to $60.86 \%$ (28 cases out of 46 ). The highest number of hyperthyroid cases were in age group of 21-30 years, $50 \%$ ( 9 out of 18 cases).
More number of hypothyroid cases were in $>40$ years age group and a smaller number of cases in $<20$ years age group. There is high association observed between age groups and thyroid type and it is found statistically significant $(\mathrm{p}<0.001)$.

Table 4: Thyroid status in AUB.

\begin{tabular}{|lll|}
\hline Thyroid status & Frequency & Percentage \\
\hline Euthyroid & 458 & $87.73 \%$ \\
\hline Hypothyroid & 46 & $8.81 \%$ \\
\hline Hyperthyroid & 18 & $3.44 \%$ \\
\hline Total & 522 & $100 \%$ \\
\hline
\end{tabular}

Table 5: Age and thyroid status.

\begin{tabular}{|llllllll|}
\hline \multirow{2}{*}{ Age } & Euthyroid & \multicolumn{3}{l}{ Hypothyroid } & \multicolumn{3}{l|}{ Hyperthyroid } \\
& No. & Percentage & No. & Percentage & No. & Percentage & Total \\
\hline$<20$ & 85 & $18.6 \%$ & 2 & $4.3 \%$ & 3 & $16.7 \%$ & 90 \\
\hline $21-30$ & 19 & $4.1 \%$ & 6 & $13.0 \%$ & 9 & $50.0 \%$ & 34 \\
\hline $31-40$ & 126 & $27.5 \%$ & 10 & $21.7 \%$ & 5 & $27.8 \%$ & 141 \\
\hline$>40$ & 228 & $49.8 \%$ & 28 & $60.9 \%$ & 1 & $5.6 \%$ & 257 \\
\hline Total & 458 & $100.0 \%$ & 46 & $100.0 \%$ & 18 & $100.0 \%$ & 522 \\
\hline
\end{tabular}

Chi square: 72.89 , p-value: $<0.001$.

Table 6: Relation of thyroid status with menstrual disturbances.

\begin{tabular}{|c|c|c|c|c|c|c|c|}
\hline \multirow{2}{*}{ Menstrual disturbance } & \multicolumn{2}{|c|}{ Euthyroid } & \multicolumn{2}{|c|}{ Hypothyroid } & \multicolumn{2}{|c|}{ Hyperthyroid } & \multirow{2}{*}{ Total } \\
\hline & No. & Percentage & No. & Percentage & No. & Percentage & \\
\hline Menorrhagia & 238 & $51.96 \%$ & 30 & $65.21 \%$ & 0 & $0 \%$ & 268 \\
\hline Polymenorrhea & 103 & $22.48 \%$ & 8 & $17.39 \%$ & 0 & $0 \%$ & 111 \\
\hline Oligomenorrhea & 60 & $13.10 \%$ & 3 & $6.50 \%$ & 10 & $55.54 \%$ & 73 \\
\hline Hypomenorrhea & 57 & $12.44 \%$ & 5 & $10.86 \%$ & 8 & $44.44 \%$ & 70 \\
\hline Total & 458 & $100 \%$ & 46 & $100 \%$ & 18 & $100 \%$ & 522 \\
\hline
\end{tabular}

Chi square: 48.05 , p-value: $<0.001$.

In hypothyroidism, menorrhagia was the commonest menstrual disorder pattern, accounting $65.21 \%$ of all menstrual pattern abnormality (30 of 46 cases). Next commonest was polymenorrhea at $17.39 \%$

In hyperthyroid group, oligomenorrhea was commonest type of menstrual disorder pattern, which was $55.54 \%$. However, hypomenorrhea was close second at $44.44 \%$.

There is high association observed between types of menstrual disturbances and thyroid type and it is found statistically significant $(\mathrm{p}<0.001)$.

\section{DISCUSSION}

AUB can lead to multitude of effects ranging from medical, social and financial issues. It can lead to serious loss of work, decrease in quality of life and drain financial resources. Therefore, early diagnosis and management can alleviate some of the concerned issues. $^{1,7}$

In this study it was observed that the incidence of AUB was more common in age group $>40$ years which was 257 of total 522 cases $(49.23 \%)$. Laxmi et al, study showed in age group 41-50 at $45.9 \%$. Mitali et al also found that it was common in $5^{\text {th }}$ decade. Even Byna $\mathrm{P}$ et al and Subedhi et al, noted highest incidence of AUB 67.27 and 53.33 respectively in the age group of 35-45. This could be explained as HPO axis dysfunction occurring in years preceding menopause..$^{8-11}$

Also, the incidence was more among multipara, which can be explained by the advanced age of mother in multipara.

Menorrhagia was the commonest menstrual disturbance among AUB cases, in our study accounting for $51.34 \%$. 
Laxmi M noted $55.3 \%$ presented with menorrhagia among all cases of AUB. In similar study done by Ajamani et al, menorrhagia accounted for $50 \%$ of all AUB. ${ }^{8,12}$

Authors studied for thyroid status was studied in all cases of AUB. Most cases were euthyroid accounting for $87.73 \%$ of all cases. Hypothyroidism was found in $8.81 \%$. Kaur et al, Sharma et al had similar incidence of hypothyroidism in cases of AUB. Authors had hyperthyroidism accounting for $3.44 \%$. Almost similar incidence was also observed in studies done by Verma $\mathrm{A}$ et al at $4 \%$. $^{13-15}$

In this study, a greater number of hypothyroid cases were in $>40$ years age group and a smaller number of cases in $<20$ years age group. Hyperthyroidism was more in age group 21-30 years. There is high association observed between age groups and thyroid disorder type and it is found statistically significant $(\mathrm{p}<0.001)$.

The commonest menstrual abnormality in hypothyroidism in this study was menorrhagia, $65.21 \%$. Verma A et al and Jinger SK et al, had similar observations. This is probably related to anovulation that occurs in hypothyroidism. ${ }^{15,16}$

In a study of 171 involving only hypothyroid patients, it was found that $76.6 \%$ had regular cycles and $23.4 \%$ had irregular cycles. Oligomenorrhea and menorrhagia was most common menstrual irregularity. The study also concluded that hypothyroidism is less frequently associated with menstrual irregularity than frequently believed. Also, it concluded that menstrual irregularities are more common in severe forms of hypothyroidism rather than milder disease. ${ }^{17}$

In this study, oligomenorrhea (55.54\%) was commonest type of abnormality seen in those with hyperthyroidism. Benson studied thyrotoxicosis patient, wherein $58 \%$ had oligomenorrhea or amenorrhea. ${ }^{18}$ This study did not find any case of amenorrhea because there were no severe thyrotoxic patients. Jinger SK et al had also observed oligomenorrhea as the most common menstrual disorder in hyperthyroidism (75\%). Authors found hypomenorrhea as the next common finding in hyperthyroidism. Jinger SK, Koutrass DA also found hypomenorrhea as the next common disorder. ${ }^{16,19}$

However, it is interesting to note that unlike hypothyroidism, hyperthyroidism in most cases does not interfere with menstruation, ovulation and pregnancy unless in severe form where it causes amenorrhea. ${ }^{20}$

In this study, there is high association observed between types of menstrual disturbances and thyroid disorder type and it is found statistically significant $(\mathrm{p}<0.001)$.

It is noticed in many studies mentioned before and including this study, the incidence of AUB in more towards perimenopause and hypothyroidism is frequent in older woman in general population, which includes perimenopausal period. This justifies screening for thyroid profile even in asymptomatic older woman. It is recommended to screen with $\mathrm{S}$. TSH assay every 5 years beginning at 35 , then every 2 years after 60 years. ${ }^{21}$

\section{CONCLUSION}

Abnormal uterine bleeding (AUB) is one of the commonest gynecological complaint at gynecological OPD. It is manifestation of various heterogeneous etiology and it is clear that thyroid dysfunction is one of them. Though certain abnormal menstrual patterns are common to specific type of thyroid disorder, it is not consistent and nor diagnostic of specific type of thyroid dysfunction.

So, it is wise to order for thyroid profile irrespective of the pattern of menstrual abnormality. Importantly, as both AUB and thyroid dysfunction are more frequent during perimenopause, testing for thyroid dysfunction should be considered as first line of investigation for AUB in that period.

Funding: No funding sources

Conflict of interest: None declared

Ethical approval: The study was approved by the Institutional Ethics Committee

\section{REFERENCES}

1. Fraser IS, Langham S, Hochgraeber K. Health related quality of life and economic burden of abnormal uterine bleeding. Expert Review Obstet Gynaecol. 2009:4(2):179-89.

2. Munro MG, Critchley, Fraser IS, Figo. Menstrual disorders committee. The two figo systems for normal and abnormal uterine bleeding symptoms and classification of causes of abnormal uterine bleeding in the reproductive years: 2018 revisions. Int $\mathbf{J}$ Gynaecol Obstet. 2018;143(3):393-408

3. Rhoades RA, Bell DR. Medical physiology, principles of clinical medicine $4^{\text {th }}$ edition: Wolter Kluwer/ Lippincot, Williams and Wilkins; 2013;621631.

4. Oumar K, Jessie DC, Peterson M. Endocrine disorders: Berek and Novak's Ggynecology. $15^{\text {th }}$ Ed. Philadephia. Lipincott Williams and Wilkins; 2012:1066-1123.

5. Von Bosedov CA. Exopthalmous durch Hypertrophie des Zellgewebes in der Augenhohle. Wchenscher Heilkunde. 1840;6:197-202.

6. Hillard PJA. Benign diseases of the female reproductive tract. Berek and Novak's Gynecology. $15^{\text {th }}$ Ed. Philadephia. Lipincott Williams and Wilkins; 2012:374-431.

7. Cote I, Jacobs P, Cunningham D. Work loss associated with increased menstrual loss in the United States. Obstet Gynecol. 2002;100:683-7. 
8. Laxmi M, Kaur P. Association of thyroid dysfunction with abnormal uterine bleeding. Int $\mathbf{J}$ Reprod Contracept Obstet Gynecol. 2018;7:2388-92.

9. Mitali M, Mishra P. Clinicopathological evaluation of abnormal uterine bleeding. J Health Res Rev. 2015;2(2):45-9.

10. Byna P, Siddula S, Kolli S, Shaik MV. Thyroid abnormality in perimenopausal women with abnormal uterine bleeding. Int $\mathrm{J}$ Res Med Sci. 2015;3(11):3250-3.

11. Subedhi S, Banerjee B, Manisha C. Thyroid disorders in women with dysfunctional bleeding. J Pathol Nepal. 2016;(6):1018-20.

12. Ajamani NS, Sarbhai V, Yadav N, Paul M, Ahmad A, Ajmani AK. Role of thyroid dysfunction in patients with menstrual disorders in tertiary care center of walled city of Delhi. J Obstet Gynaecol. India. 2016;66(2):115-9.

13. Kaur T, Aseeja V, Sharma S. Thyroid dysfunction in dysfunctional uterine bleeding. Obstet Gynecol. 2011;2(9):WCM002235.

14. Sharma N, Sharma A. Thyroid profile in menstrual disorders. J K Sci. 2012;14(1):14-7.

15. Verma A, Kaur AP, Shergill HK, Kaur S. Menstrual disorders in thyroid dysfunction. EJBPS. 2017;4(2):197-201.

16. Jinger SK, Verma A, Dayma I, Talreja T. To study the thyroid profile in menstrual disorder at tertiary care hospital in northern western Rajasthan, India. Int J Res Med Sci. 2017;5(5):2212-4.

17. Krassas GE, Pontikides N, Kaltsas TH, Papadopoulou PH, Paunkovic J, Paunkovic N, et al. Disturbances of menstruation in hypothyroidism. Clin Endocrinol. 1999;50(5):655-9.

18. Benson RC, Dailey ME. Menstrual pattern in hyperthyroidism and subsequent post-therapy hypothyroidism. Surg Gynaecol Obstet. 1955:100:19-26.

19. Koutras DA. Disturbances of menstruation in thyroid disease. Ann N Y Acad Sci. 1997;816:280-4.

20. Mandel SJ, Brent GA, LARSEN PR. Review of antithyroid drug use during pregnancy and report of a case of aplasia cutis. Thyroid. 1994;4(1):129-33.

21. Reproduction and Thyroid. In: Hugh S Taylor,Lubna Pal, Emre Seli. eds. Speroff's Clinical Endocrinology and Infertility. $9^{\text {th }}$ Ed. Philedelphia. Wolter Kluwer; 2020:1979-2026.

Cite this article as: Hema KR, Girish BL, Dhananjaya BS, Kalaburgi RA. Prevalence of thyroid dysfunction in women with abnormal uterine bleeding in reproductive age. Int J Reprod Contracept Obstet Gynecol 2020;9:2792-6. 